\title{
Circulating tumour cells and hypercoagulability: a lethal relationship in metastatic breast cancer
}

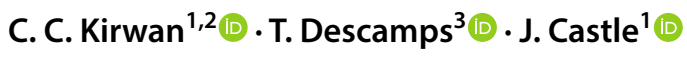

Received: 11 June 2019 / Accepted: 28 July 2019 / Published online: 31 August 2019

(c) The Author(s) 2019

\begin{abstract}
Purpose Circulating tumour cells (CTCs) are a marker of poor prognosis and are associated with increased risk of venous thromboembolism in metastatic breast cancer (MBC). We aimed to determine if the presence of CTCs and plasma markers of hypercoagulability [thrombin-antithrombin III (TAT), fibrinogen and D-dimer] are biomarkers of survival in MBC. Methods/patients In a prospective study of MBC patients, CTC $\left(\right.$ CellSearch $\left.^{\circledR}\right)$ enumeration and plasma TAT, fibrinogen and D-dimer measured prior to commencement of treatment for disease progression were correlated to overall survival.

Results At study completion, of $50 \mathrm{MBC}$ patients recruited (median age 59 years, range 36-82), 40 patients had died (median survival 417 days, range 58-2141). CTCs $(\geq 1 / 7.5 \mathrm{ml}$ ) were identified in 16 patients (median number of cells per $7.5 \mathrm{ml}, 3$ (range 1-31) and were associated with systemic hypercoagulability (medians TAT: $8.1 \mathrm{vs.} 5.2 \mathrm{ng} / \mathrm{ml}, p=0.03$; fibrinogen: 4.3 vs. $3.1 \mathrm{~g} / \mathrm{l}, p=0.03$; D-dimer: 1327 vs. $683 \mathrm{ng} / \mathrm{ml}, p=0.0001)$. At 1 year, of 16 patients with $\geq 1 \mathrm{CTC}, 7$ had died (44\%), compared to 5 of $26(19 \%)$ patients in the no-CTC group. The presence of $\geq 1$ CTC was associated with a trend for reduced overall survival (median 455 days vs. 614 days, $p=0.15$ ). Plasma TAT inversely correlated with survival and was significantly higher in patients dying within 1 year (median $9.8 \mathrm{vs.} 5.2 \mathrm{ng} / \mathrm{ml}, p=0.004$ ) whilst D-dimer showed a trend for reduced 1 -year survival (median 1211 vs. $817 \mathrm{ng} / \mathrm{ml}, p=0.06$ ). MBC patients with combined high D-dimer ( $\geq 895 \mathrm{ng} / \mathrm{ml}$ ) and CTC positivity ( $\geq 1 / 7.5 \mathrm{ml}$ whole peripheral blood) had significantly reduced survival $(p=0.04)$.

Conclusions The correlation between CTCs, hypercoagulability and reduced survival in MBC suggests the coagulation system supports tumour cell metastasis and is, therefore, a potential therapeutic target.
\end{abstract}

Keywords Coagulation $\cdot$ CTC $\cdot$ TAT $\cdot$ Fibrinogen $\cdot$ D-Dimer $\cdot$ Survival

Electronic supplementary material The online version of this article (https://doi.org/10.1007/s12094-019-02197-6) contains supplementary material, which is available to authorized users.

C. C. Kirwan

cliona.kirwan@manchester.ac.uk

T. Descamps

tine.descamps@cruk.manchester.ac.uk

J. Castle

john.castle@manchester.ac.uk

1 Division of Cancer Sciences, Faculty of Biology, Medicine and Health, School of Medical Sciences, Manchester Cancer Research Centre, University of Manchester, Wilmslow Road, Manchester M20 4GJ, UK

\section{Introduction}

Venous thromboembolism (VTE) in cancer is common and a major cause of death. Breast cancer is associated with a three- to fourfold increased risk of venous thromboembolism (VTE) compared to age-matched women without cancer [1, 2]. Cancer patients who develop VTE have a worse cancer

2 Wythenshawe Hospital, Manchester University NHS Foundation Trust, Manchester Academic Health Science Centre, Southmoor Road, Wythenshawe, Manchester M23 9LT, UK

3 Centre for Cancer Biomarker Sciences, Cancer Research UK Manchester Institute, University of Manchester, Alderley Park, Macclesfield SK10 4TG, UK 
prognosis than those that remain free of VTE, implying VTE is a surrogate marker for aggressive cancer [3-5].

Approximately half of all cancer patients and $90 \%$ of metastatic patients exhibit coagulation abnormalities. This is reflected in activation of the clotting cascade [6], platelet activation [7] and alterations of fibrinolytic activity [8] resulting in clinical and biochemical evidence of coagulation $[9,10]$. Thrombin-antithrombin III (TAT) complex plasma concentration is used to assess activation of the coagulation system as a surrogate marker for activated thrombin [11]. Plasma TAT and D-dimer are higher in early-breast cancer patients than in healthy controls [12]. Circulating fibrinogen, which is converted to fibrin by thrombin, has showed utility in distinguishing breast cancer from benign breast disease [13], and increases with disease progression [14]. D-dimer (a product of fibrin degradation and the end product of coagulation activation) is increased in breast cancer, with raised levels being found in 58\% of patients with involved lymph nodes, and only $8 \%$ of patients without lymph node disease [10].

Many coagulation factors can be identified in the tumour stroma and cancer cells [15]. Tumour cells can activate all components of the haemostatic system, for example the procoagulant potential of cancer cells has a linear relationship with their tissue factor expression [16]. However, there appears to be a two-way association between coagulation and cancer. Components of the haemostatic system promote tumour growth and metastasis, with thrombin increasing proliferation, migration and angiogenesis in preclinical models $[17,18]$. Tissue factor has furthermore been identified as a promoter of cancer stem cell activity [19].

Circulating tumour cells (CTCs) are cells from a primary tumour that have entered the vasculature or lymphatics, and are the principal mechanism for development of metastases. First described by Ashworth [20], the field of CTC research has grown exponentially, with the hope that CTC assessment will act as real-time predictive and prognostic biomarker. Using the commercially available CellSearch ${ }^{\circledR}$ assay (Menarini Group, Italy), CTC number predicts for reduced progression-free survival (PFS) and overall survival (OS) in several MBC studies [21-24]. CellSearch CTC number is also a potential prognostic biomarker and a predictive biomarker for response to chemotherapy and endocrine therapy in MBC patients [25, 26].

\section{Hypothesis}

We hypothesise that the symbiotic relationship between CTCs and plasma coagulation results in more effective dissemination of metastases, reflects more aggressive disease and correlates with reduced survival in MBC. We aimed to determine if the combination of CTC enumeration and quantification of systemic hypercoagulability [thrombin-antithrombin III (TAT), fibrinogen and D-dimer] is a biomarker of reduced overall survival in MBC.

\section{Methods}

A prospective cohort of metastatic breast cancer patients $(n=50)$ were recruited at The Christie NHS Foundation Trust Hospital (Manchester, UK) between February 2013 and June 2015 (TuFClot, Tumour Fragments and Clotting). Follow-up was until July 2019. All had either a new diagnosis of metastatic disease or new evidence of clinical or radiological disease progression. Patients on anticoagulation therapy or with a known non-breast cancer within the last 5 years were excluded. This study was approved by UK National Research Ethics Service (NRES) Committee North West-Greater Manchester Central Ethics Committee (Ref: 12/NW/0447) and sponsored by Manchester University NHS Foundation Trust. Written informed consent was obtained from all individual participants included in the study.

This clinical study report has been written with the guidance of the reporting recommendations for tumour marker prognostic studies (REMARK) [27].

\section{Blood sampling}

Peripheral venous blood was collected using CellSave preservative (Menarini, Italy, Cat\# 7900005) and citrate vacutainer tubes (BD Biosciences, NJ USA, Cat\# 363095) for CellSearch $^{\circledR}$ circulating tumour cell (CTC) analysis and platelet poor plasma preparation, respectively. Blood was collected prior to treatment for disease progression. CellSave whole blood samples were stored at room temperature until analysis.

For TAT, fibrinogen and D-dimer analysis, citrate tubes were centrifuged within $60 \mathrm{~min}$ of blood taking in a precooled centrifuge at $4{ }^{\circ} \mathrm{C}$ for $20 \mathrm{~min}$ at $2500 \mathrm{~g}$. Plasma was pipetted into a clear tube leaving the cell pellet and centrifuged again at $4{ }^{\circ} \mathrm{C}$ for $20 \mathrm{~min}$ at $2500 \mathrm{~g}$. The platelet poor plasma was aliquoted into cryovials and stored at $-80^{\circ} \mathrm{C}$ until analysis, with the final $0.5 \mathrm{ml}$ in the clear tube discarded.

Analysis of whole blood and plasma samples was carried out by analysts trained in good clinical practice (GCP) who were blinded to patient outcome data.

\section{CellSearch $^{\circledast}$ circulating tumour cell (CTC) analysis}

CellSave blood samples $(7.5 \mathrm{ml})$ were processed by the CellSearch ${ }^{\circledR}$ system in the Clinical and Experimental Pharmacology (CEP) group at the Cancer Research UK Manchester Institute (CRUK MI) as described elsewhere 
[21]. Briefly, CTCs are immunomagnetically separated from other blood components by EpCAM (epithelial cell adhesion molecule) antibody-conjugated beads and then stained for cytokeratins (CKs 8, 18 and 19) and CD45 in a fluorescent-based approach. CTCs are defined as CK+ CD45- cells over $4 \mu \mathrm{m}$ in diameter (Supp. Figure 1). CellSearch CTC Control Kits (Cat\# 7900003) were used as a quality control to ensure reagent, instrument and operator performance.

Supplementary Figure 1 represents the gallery of images shown on the CellSearch ${ }^{\circledR}$ Analyzer after CTC enrichment from blood using EpCAM antibodies and staining. Cells $\geq 4 \mu \mathrm{m}$ immunofluorescently staining for cytokeratins and not CD45 are scored as CTCs. The event shown was scored as a CTC by trained analysts.

\section{TAT, fibrinogen and D-dimer analysis}

Plasma was analysed using Siemens AG (Berlin, Germany) Enzygnost ${ }^{\circledR}$ TAT micro-enzyme immunoassays (Cat\# OWMG15) in the CEP group at CRUK MI. Validation work was carried out prior to analysis to ensure fit for purpose. Plasma was analysed for fibrinogen and D-dimer using a Werfen (Warrington, UK) ACL TOP 500 automated haemostasis testing system in the Haematology Department at Wythenshawe Hospital. HemosIL ${ }^{\circledR}$ Q.F.A. Thrombin clotting assay (Cat\# 0020301700) and D-dimer HS 500 immunoassay (Cat\# 0020500100) reagents were used to quantify fibrinogen and D-dimer, respectively.

\section{Statistical analysis}

GraphPad Prism software version 7 (CA, USA) was used for primary statistical analysis and graph preparation. Raw TAT, fibrinogen and D-dimer data was $\log _{2}$ transformed to allow parametric testing after 1 was added to each raw value to prevent $\log _{2}$ values $\leq 0$. Normality of the transformed coagulation marker data was confirmed by D'Agostino and Pearson testing. Coagulation marker groups were compared using unpaired two-tailed $t$ tests, and raw coagulation values were dichotomised around the median value to allow comparison of high versus low.

The percentage survival at 1 year was reported. Overall survival was measured as days from study entry till death or censored at last follow-up (with a minimal follow-up of 365 days), until July 2019. Log-rank (Mantel-Cox) regression was performed to assess survival between patient groups. The proportionality of hazard assumptions for use of the Cox model was verified based on Schoenfeld residuals using the statistical computing software R [28].

\section{Results}

Of the $50 \mathrm{MBC}$ patients recruited, median age was 59 years (range 36-82), 66\% were oestrogen receptor (ER) positive, $32 \%$ were Her 2 positive and $12 \%$ had bone metastases only (Table 1). At 1-year follow-up 16 patients had died. At final follow-up in July 2019, 40 patients had died, median survival 417 days, range 58-2141 days.

Eight patients had no CTC result due to insufficient blood sample or CellSearch equipment failure. Insufficient plasma samples led to missing patient results for TAT analysis ( 9 out of 50 patients), fibrinogen (16/50) and D-dimer (10/50).

The datasets generated and analysed during the TuFClot study are available in the Mendeley Data repository, https:// dx.doi.org/10.17632/742ftgfg54.2 [29].

Circulating tumour cells, CTCs $(\geq 1 / 7.5 \mathrm{ml}$ whole peripheral blood) were identified in 16 out of $42 \mathrm{MBC}$ patients (38.1\%) [median number of cells per $7.5 \mathrm{ml}, 3$ (range 1-31)]. CTC positivity ( $\geq 1 / 7.5 \mathrm{ml}$ ) was associated with hypercoagulability (TAT: median 8.1 vs. $5.2 \mathrm{ng} / \mathrm{ml}, p=0.03$; fibrinogen: median 4.3 vs. $3.1 \mathrm{~g} / \mathrm{l}, p=0.03$; D-dimer: median 1327 vs. $683 \mathrm{ng} / \mathrm{ml}, p=0.0001)$. Taking the more rigorous definition of CTC positivity as $\geq 2 / 7.5 \mathrm{ml}$ whole peripheral blood, $\mathrm{CTC} \geq 2 / 7.5 \mathrm{ml}(n=12)$ was also associated with increased D-dimer but not fibrinogen or TAT: median 1815 vs. $741 \mathrm{ng} /$ $\mathrm{ml}, p<0.01$ (Fig. 1).

CTC count did not correlate with ER or Her2 status, or the presence of visceral and locally advanced compared to bone-only metastases. The presence of $\geq 1$ CTC was associated with a trend for reduced overall survival (median

Table 1 TuFClot study metastatic breast cancer patient demographics

\begin{tabular}{lc}
\hline & $n(\%)$ \\
\hline Receptor status & \\
ER+, Her2- & $26(52)$ \\
ER+, Her2+ & $7(14)$ \\
ER-, Her2+ & $9(18)$ \\
Triple negative & $8(16)$ \\
Metastatic sites & \\
Bone only & $6(12)$ \\
Locally advanced & $3(6)$ \\
Single visceral site & \\
Liver & $12(24)$ \\
Lung & $12(24)$ \\
Brain & $2(4)$ \\
Other & $1(2)$ \\
Multiple visceral sites $(\geq 2)$ & $14(28)$ \\
\hline
\end{tabular}

Oestrogen receptor (ER) values were reported as a Modified Quick Score (QS) for all patients. A QS value of 0-2 was considered negative, $3-8$ positive 
Fig. 1 Circulating tumour cells (CTCs) are associated with increased coagulation plasma markers in metastatic breast cancer. CTC number in $7.5 \mathrm{ml}$ peripheral whole blood samples enumerated by the CellSearch technology compared to plasma coagulation markers a thrombin-antithrombin III complex (TAT), b fibrinogen and $\mathbf{c}, \mathbf{d}$ D-dimer in metastatic breast cancer (MBC) patients. Unpaired two-tailed $t$ tests comparing $\log _{2}$ transformed raw coagulation marker concentrations +1 to CTC group, ${ }^{*} p<0.05, * * p<0.01$, $* * * p<0.001$. Error bars show standard error of the mean (SEM); $n$ number of MBC patients in each group, TAT thrombin-antithrombin III complex, CTC circulating tumour cell
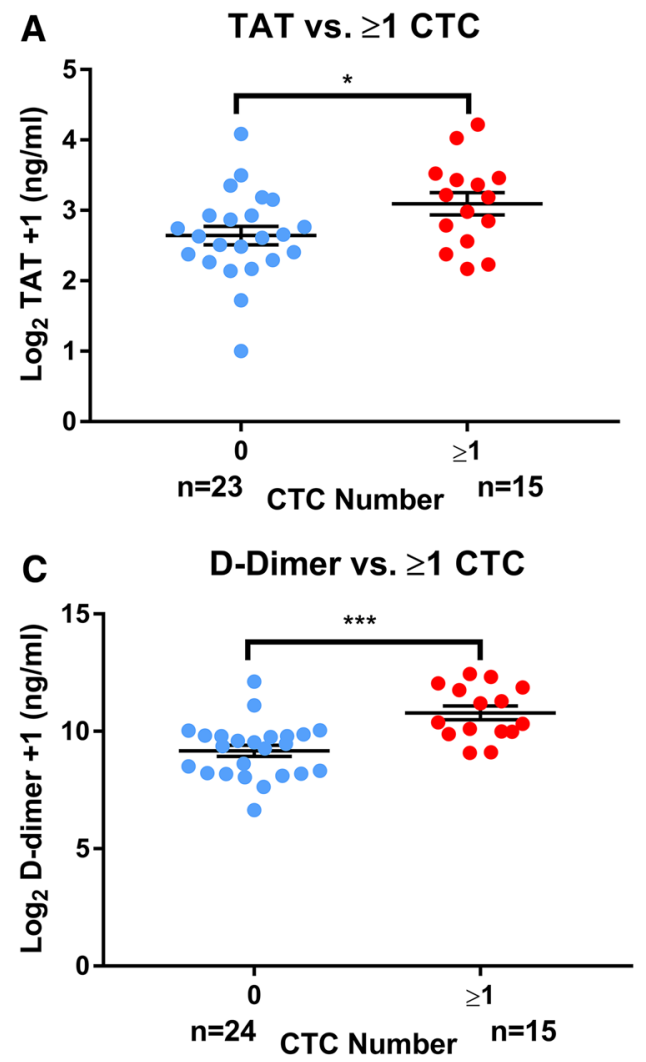

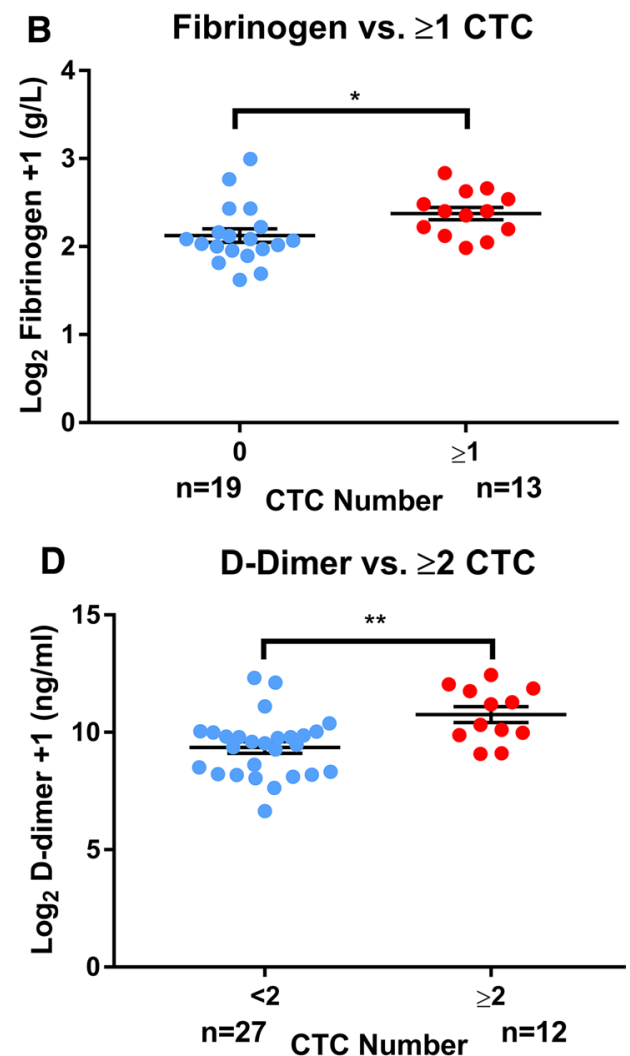

455 days vs. 614 days, $p=0.15$, Fig. 2). At 1 year, of 16 patients with $\geq 1 \mathrm{CTC}, 7$ had died (44\%), compared to 5 of $26(19 \%)$ in the no-CTC group, however, this was not statistically significant.

Plasma markers of coagulation did not correlate with ER or Her2 status, or the presence of visceral and locally advanced compared to bone-only metastases. Fibrinogen was not associated with reduced survival, however, plasma TAT was significantly higher in MBC patients dying within 1 year post-recruitment compared to those who survived over a year (median 9.8 vs. $5.2 \mathrm{ng} / \mathrm{ml}, p=0.004$ ) whilst D-dimer showed a trend for this (median $1211 \mathrm{vs.} 817 \mathrm{ng} /$ $\mathrm{ml}, p=0.06)$. When dichotomised into high $(<5.9 \mathrm{ng} / \mathrm{ml})$ and low $(\geq 5.9 \mathrm{ng} / \mathrm{ml})$, TAT was associated with significantly reduced survival ( $p<0.01$, Fig. 3).

MBC patients with a combined high D-dimer $(\geq 895 \mathrm{ng} /$ $\mathrm{ml})$ and CTC positive ( $\geq 1 / 7.5 \mathrm{ml}$ whole peripheral blood) had significantly reduced survival by log-rank (Mantel-Cox) testing ( $p=0.04$, Fig. 4$)$.

\section{Discussion}

The trend for reduced overall survival in MBC patients with $\geq 1 \mathrm{CTCs} / 7.5 \mathrm{ml}$ whole blood is consistent with previous reports $[30,31]$.

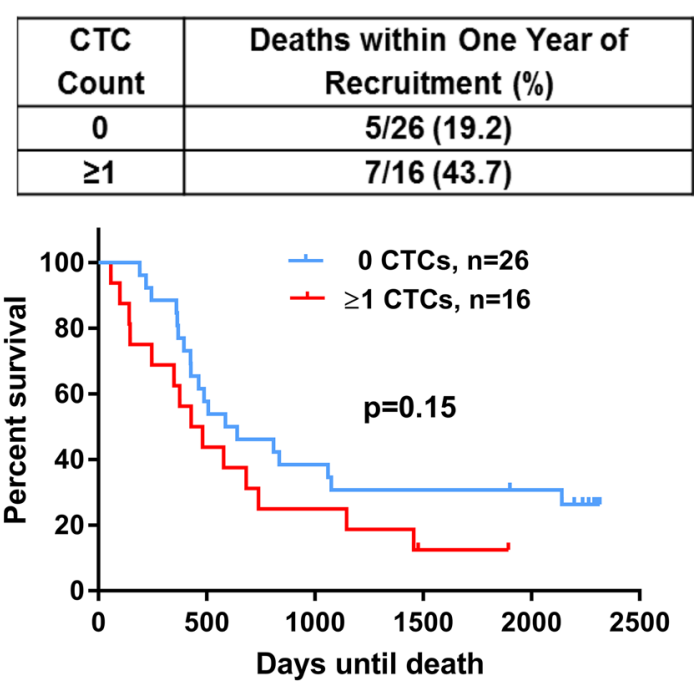

Fig. 2 Trend for reduced overall survival in circulating tumour cell (CTC)-positive metastatic breast cancer patients. CTC number in $7.5 \mathrm{ml}$ peripheral whole blood samples enumerated by the CellSearch technology was enumerated in metastatic breast cancer (MBC) patients. Log-rank (Mantel-Cox) testing compared survival in days from study entry in CTC-positive compared to CTC-negative patients. CTC positive defined as $\geq 1 / 7.5 \mathrm{ml}$. Assumption of proportionality was verified based on Schoenfeld residuals; $n$ number of MBC patients in each group, $C T C$ circulating tumour cell 

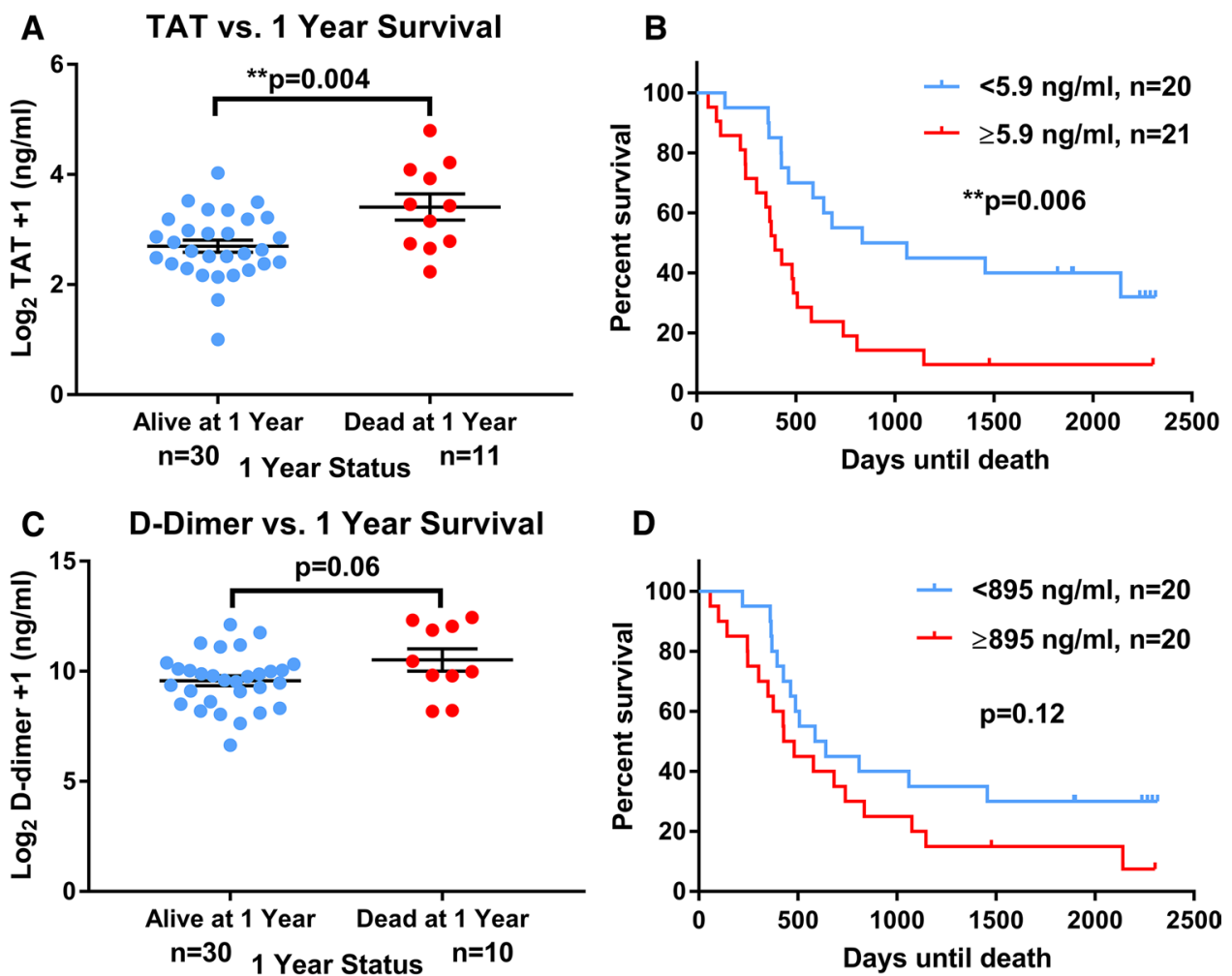

Fig. 3 Coagulation plasma markers TAT and D-dimer are associated with poorer survival in metastatic breast cancer. Coagulation markers thrombin-antithrombin III complex (TAT) and D-dimer were quantified by immunoassay in metastatic breast cancer (MBC) patient plasma samples. a TAT, $\mathbf{c}$ D-dimer: unpaired two-tailed $t$ tests of $\log _{2}$ transformed raw coagulation marker concentrations compared to survival groups, ${ }^{* *} p<0.01$. Error bars show standard error of the mean

(SEM). b TAT, d D-dimer: log-rank (Mantel-Cox) tests comparing survival in days from study entry in these coagulation markers dichotomised around the median values (TAT $5.9 \mathrm{mg} / \mathrm{ml}$, D-dimer $895 \mathrm{ng} /$ $\mathrm{ml})$ were carried out, $* * p<0.01$. Assumption of proportionality was verified based on Schoenfeld residuals; $n$ number of MBC patients in each group, TAT thrombin-antithrombin III complex

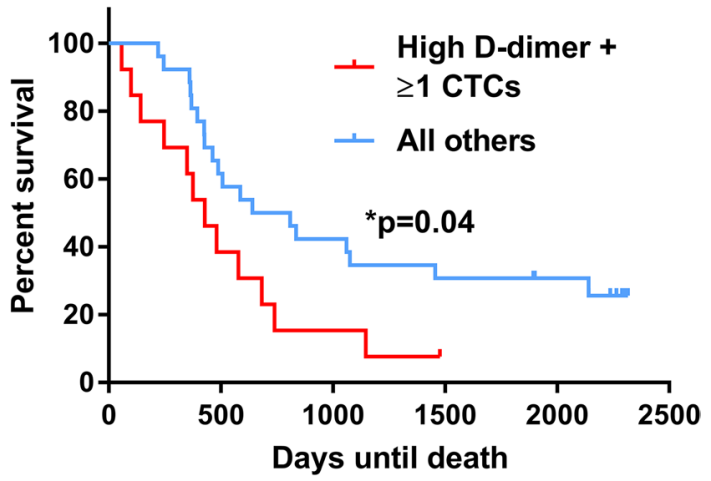

Fig. 4 The combined presence of a high D-dimer and circulating tumour cell positivity is associated with reduced survival in metastatic breast cancer. Survival in patients with CTC positive $(\geq 1$ $\mathrm{CTCs} / 7.5 \mathrm{ml})$ and high D-dimer $(\geq 895 \mathrm{ng} / \mathrm{ml})$ (red line, $n=13)$ was compared to all other patients (blue line, $n=26$ ). A log-rank (MantelCox) test comparing survival in days from study entry in the shown CTC/coagulation marker groups was performed. Assumption of proportionality was verified based on Schoenfeld residuals; $n$ number of $\mathrm{MBC}$ patients in each group, CTC circulating tumour cell

The very significant association between plasma TAT and overall survival supports previous work from our team demonstrating higher concentrations of TAT in metastatic compared to early breast cancer patients or age-matched female controls [6]. To our knowledge, here we report the first association between plasma TAT and metastatic breast cancer survival. The trend found between plasma D-dimer and survival supports the findings of Dirix et al. who showed D-dimer to be increased in patients with metastatic compared to early breast cancer or healthy female volunteers and correlates with tumour volume and overall survival [32]. D-dimer has furthermore been reported to be associated with lymphovascular invasion, clinical stage and lymph node involvement in early breast cancer patients, indicating its potential as a prognostic biomarker [10].

The correlation between CTC positivity and plasma coagulation we report here is reflected clinically by the work of Mego et al. [33], where they reported CTC presence was associated with higher plasma D-dimer levels in MBC patients. Both Mego's findings and or current findings of the association of hypercoagulability and CTCs likely 
reflects the known symbiotic relationship between circulating tumour cells and the haemostatic system. Tissue factor, the main initiator of the extrinsic pathway of coagulation, assists CTC survival by inhibition of anchorage-dependent apoptosis (anoikis) and through promotion of the epithelial-mesenchymal transition [19, 34, 35]. This was shown to be a two-way relationship by Bourcy et al. who defined a novel induction of tissue factor expression by EMT that drove metastasis in breast cancer. CTCs were shown to jointly express tissue factor and vimentin in MBC patients [36]. Fibrin deposition and platelet activation have been shown to create a 'thrombus cloak' that protects circulating CTCs from natural killer cells in murine models $[37,38]$. Platelet-derived cytokines have furthermore been demonstrated to block natural killer cell activity, therefore providing a protective effect on CTCs in the bloodstream [39].

Coagulation factors may also help CTCs to extravasate from the vasculature. Platelets help trap CTCs in bloods vessels [40] with ligands expressed by activated platelets aiding adherence to the vascular endothelium [41]. It is postulated that breast cancer CTC expression of tissue factor results in localised fibrin creation, trapping CTCs in platelet-fibrin microemboli and promoting early metastatic seeding into distant organs [36]. Although we did not find any correlation between ER/Her2 status or the site of metastases and CTCs/ plasma coagulation, this may simply reflect the small sample size. However, coagulation factor aided-extravasation could provide an explanation for the significantly poorer survival in MBC patients with a combined CTC positivity and high D-dimer, indicating a hypercoagulable microenvironment resulting in increased metastatic potential and worse outcome.

This link between plasma coagulation, CTCs and survival suggests a potential improvement in breast cancer outcome could be achieved by therapeutic targeting of the coagulation system. In vivo breast cancer xenograft models have demonstrated a reduction in tumour growth and metastasis using anti-tissue factor antibodies $[42,43]$. The direct thrombin inhibitor dabigatran has also shown efficacy in reducing tumour growth and liver micrometastases in a breast cancer murine model, indicating an anti-cancer effect of the direct oral anticoagulant (DOAC) class of drugs [44]. We are currently studying Rivaroxaban, a DOAC licensed for the prophylaxis and treatment of VTE that is an inhibitor of Factor Xa, thereby inhibiting the TF-Factor VIIa-Factor Xa complex, in a Phase II trial of early breast cancer patients (TIP Trial, EudraCT No.: 2014-004909-33) [45].

In conclusion, this study demonstrates the potential for combining CTC enumeration and assessment of systemic hypercoagulability using TAT or D-dimer as a prognostic biomarker in MBC. In addition, through demonstrating a correlation between hypercoagulability and CTC, this supports the hypothesis that coagulation is mechanistic in promoting CTC intravasation and CTC survival. The coagulation system may, therefore, be a potential therapeutic target in breast cancer.

Acknowledgements Patient recruitment was supported by Janine Hurst and Research Nurses at the Christie Hospital. Circulating tumour cell and plasma analysis was carried out with the help of Professor Caroline Dive and the Cells and Protein Team at the Clinical and Experimental Pharmacology group, Cancer Research UK Manchester Institute. Patient survival data were collected with the help of Doctor Sacha Howell at the Manchester University NHS Foundation Trust.

Funding This work was supported by The Bupa Foundation (Grant number: TBF-M10-041), Academy of Medical Sciences, and University Hospital of South Manchester Research Endowment Fund. C.C. Kirwan is supported by a National Institute of Health Research Clinician Scientist Award (NIHR-CS-011014). T. Descamps is supported by a Cancer Research UK Manchester Centre Award (A25254), Manchester Experimental Cancer Medicine Centre (A25146) and the NIHR Manchester Biomedical Research Centre.

\section{Compliance with ethical standards}

Conflict of interest The authors declare that they have no conflict of interest.

Ethical approval All the procedures performed in this study involving human participants were in accordance with the ethical standards of the institutional and/or national research committee (UK National Research Ethics Service (NRES) Committee North West-Greater Manchester Central Ethics Committee Ref: 12/NW/0447) and with the 1964 Helsinki Declaration and its later amendments or comparable ethical standards.

Informed consent Informed consent was obtained from all individual participants included in this study.

Open Access This article is distributed under the terms of the Creative Commons Attribution 4.0 International License (http://creativecommons.org/licenses/by/4.0/), which permits unrestricted use, distribution, and reproduction in any medium, provided you give appropriate credit to the original author(s) and the source, provide a link to the Creative Commons license, and indicate if changes were made.

\section{References}

1. Walker AJ, Card TR, West J, Crooks C, Grainge MJ. Incidence of venous thromboembolism in patients with cancer-a cohort study using linked United Kingdom databases. Eur J Cancer. 2013;49(6):1404-13 (PubMed PMID: 23146958).

2. Cronin-Fenton DP, Sondergaard F, Pedersen LA, Fryzek JP, Cetin $\mathrm{K}$, Acquavella J, et al. Hospitalisation for venous thromboembolism in cancer patients and the general population: a population-based cohort study in Denmark, 1997-2006. Br J Cancer. 2010;103(7):947-53 (PubMed PMID: 20842120, Pubmed Central PMCID: 2965880).

3. Morgan MA, Iyengar TD, Napiorkowski BE, Rubin SC, Mikuta JJ. The clinical course of deep vein thrombosis in patients with gynecologic cancer. Gynecol Oncol. 2002;84(1):67-71 (PubMed PMID: 11748979). 
4. Weiss RB, Tormey DC, Holland JF, Weinberg VE. Venous thrombosis during multimodal treatment of primary breast carcinoma. Cancer Treat Rep. 1981;65(7-8):677-9 (PubMed PMID: 7248984).

5. Levitan N, Dowlati A, Remick SC, Tahsildar HI, Sivinski LD, Beyth R, et al. Rates of initial and recurrent thromboembolic disease among patients with malignancy versus those without malignancy. Risk analysis using Medicare claims data. Medicine (Baltimore). 1999;78(5):285-91 (PubMed PMID: 10499070).

6. Kirwan CC, McDowell G, McCollum CN, Kumar S, Byrne GJ. Early changes in the haemostatic and procoagulant systems after chemotherapy for breast cancer. Br J Cancer. 2008;99(7):1000-6 (PubMed PMID: 18766191. Pubmed Central PMCID: 2567096).

7. Dymicka-Piekarska V, Kemona H. Does colorectal cancer clinical advancement affect adhesion molecules (sP-selectin, sE-selectin and ICAM-1) concentration? Thromb Res. 2009;124:80-3 (PubMed PMID: 19136145).

8. Nielsen HJ, Pappot H, Christensen IJ, Brunner N, ThorlaciusUssing $\mathrm{O}$, Moesgaard $\mathrm{F}$, et al. Association between plasma concentrations of plasminogen activator inhibitor- 1 and survival in patients with colorectal cancer. BMJ. 1998;316(7134):829-30 (PubMed PMID: 9549453).

9. Lee AY. Cancer and thromboembolic disease: pathogenic mechanisms. Cancer Treat Rev. 2002;28(3):137-40 (PubMed PMID: 12234564)

10. Blackwell K, Haroon Z, Broadwater G, Berry D, Harris L, Iglehart $\mathrm{JD}$, et al. Plasma D-dimer levels in operable breast cancer patients correlate with clinical stage and axillary lymph node status. J Clin Oncol. 2000;18(3):600-8 (PubMed PMID: 10653875).

11. Blanke H, Praetorius G, Leschke M, Seitz R, Egbring R, Strauer BE. Significance of the thrombin-antithrombin III complex in the diagnosis of pulmonary embolism and deep venous thrombosis-comparison with fibrinopeptide A, platelet factor 4 and betathromboglobulin. Klinische Wochenschrift. 1987;65(16):757-63 (PubMed PMID: 2958657. Die Bedeutung des ThrombinAntithrombin III-Komplexes in der Diagnostik der Lungenembolie und der tiefen Venenthrombose-Vergleich mit Fibrinopeptid A, Plattchenfaktor 4 und beta-Thromboglobulin).

12. Topcu TO, Kavgaci H, Canyilmaz E, Orem A, Yaman H, Us D, et al. The effect of adjuvant chemotherapy on plasma TAT and $\mathrm{F}$ $1+2$ levels in patients with breast cancer. Biomed Pharmacother. 2015;73:19-23 (PubMed PMID: 26211577).

13. Fu S, Yun ZY, Cui MM, Meng H, Qian C, Liu T, et al. Cancer antigen 15-3, platelet distribution width, and fibrinogen in combination to distinguish breast cancer from benign breast disease in non-conclusive mammography patients. Oncotarget. 2017;8(40):67829-936 (PubMed PMID: 28978076, Pubmed Central PMCID: 5620216).

14. Edwards RL, Rickles FR, Moritz TE, Henderson WG, Zacharski LR, Forman WB, et al. Abnormalities of blood coagulation tests in patients with cancer. Am J Clin Pathol. 1987;88(5):596-602 (PubMed PMID: 3673941).

15. Gordon SG. Cancer cell procoagulants and their role in malignant disease. Semin Thromb Hemost. 1992;18(4):424-33 (PubMed PMID: 1470929).

16. Welsh J, Smith JD, Yates KR, Greenman J, Maraveyas A, Madden LA. Tissue factor expression determines tumour cell coagulation kinetics. Int J Lab Hematol. 2012;34(4):396-402 (PubMed PMID: 22348286)

17. Vianello F, Sambado L, Goss A, Fabris F, Prandoni P. Dabigatran antagonizes growth, cell-cycle progression, migration, and endothelial tube formation induced by thrombin in breast and glioblastoma cell lines. Cancer Med. 2016;5(10):2886-988 (PubMed PMID: 27600331, Pubmed Central PMCID: 5083743).
18. Henrikson KP, Salazar SL, Fenton JW II, Pentecost BT. Role of thrombin receptor in breast cancer invasiveness. Br J Cancer. 1999;79(3-4):401-6 (PubMed PMID: 10027305. Pubmed Central PMCID: 2362433).

19. Shaker H, Harrison H, Clarke R, Landberg G, Bundred NJ, Versteeg $\mathrm{HH}$, et al. Tissue factor promotes breast cancer stem cell activity in vitro. Oncotarget. 2017;8(16):25915-27 (PubMed PMID: 28033108, Pubmed Central PMCID: 5432226).

20. Ashworth TR. A case of cancer in which cells similar to those in the tumours were seen in the blood after death. Aust Med J. $1869 ; 14: 146-7$.

21. Cristofanilli M, Budd GT, Ellis MJ, Stopeck A, Matera J, Miller MC, et al. Circulating tumor cells, disease progression, and survival in metastatic breast cancer. N Engl J Med. 2004;351(8):781-91 (PubMed PMID: 15317891).

22. Pierga JY, Hajage D, Bachelot T, Delaloge S, Brain E, Campone $\mathrm{M}$, et al. High independent prognostic and predictive value of circulating tumor cells compared with serum tumor markers in a large prospective trial in first-line chemotherapy for metastatic breast cancer patients. Ann Oncol. 2012;23(3):618-24 (PubMed PMID: 21642515).

23. Nole F, Munzone E, Zorzino L, Minchella I, Salvatici M, Botteri E, et al. Variation of circulating tumor cell levels during treatment of metastatic breast cancer: prognostic and therapeutic implications. Ann Oncol. 2008;19(5):891-7 (PubMed PMID: 18056915).

24. Liu MC, Shields PG, Warren RD, Cohen P, Wilkinson M, Ottaviano YL, et al. Circulating tumor cells: a useful predictor of treatment efficacy in metastatic breast cancer. J Clin Oncol. 2009;27(31):5153-9 (PubMed PMID: 19752342, Pubmed Central PMCID: 4879719).

25. Giuliano M, Giordano A, Jackson S, Hess KR, De Giorgi U, Mego M, et al. Circulating tumor cells as prognostic and predictive markers in metastatic breast cancer patients receiving first-line systemic treatment. Breast Cancer Res BCR. 2011;13(3):R67 (PubMed PMID: 21699723, Pubmed Central PMCID: 3218956).

26. Nakamura S, Yagata H, Ohno S, Yamaguchi H, Iwata H, Tsunoda $\mathrm{N}$, et al. Multi-center study evaluating circulating tumor cells as a surrogate for response to treatment and overall survival in metastatic breast cancer. Breast Cancer. 2010;17(3):199-204 (PubMed PMID: 19649686).

27. McShane LM, Altman DG, Sauerbrei W, Taube SE, Gion M, Clark GM, et al. REporting recommendations for tumour MARKer prognostic studies (REMARK). Br J Cancer. 2005;93(4):387-91 (PubMed PMID: 16106245, Pubmed Central PMCID: 2361579).

28. R Core Team. R: a language and environment for statistical computing. Vienna: R Foundation for Statistical Computing; 2018. https://www.R-project.org. Accessed 11 June 2019.

29. Castle J, Kirwan C, Descamps T. TuFClot Study Raw Data 04JUL2019, Mendeley Data, v2. 2019. https://doi.org/10.17632 $1742 \mathrm{ftgfg} 54.2$.

30. Huebner H, Fasching PA, Gumbrecht W, Jud S, Rauh C, Matzas $\mathrm{M}$, et al. Filtration based assessment of CTCs and CellSearch(R) based assessment are both powerful predictors of prognosis for metastatic breast cancer patients. BMC Cancer. 2018;18(1):204 (PubMed PMID: 29463222, Pubmed Central PMCID: 5819661).

31. Botteri E, Sandri MT, Bagnardi V, Munzone E, Zorzino L, Rotmensz N, et al. Modeling the relationship between circulating tumour cells number and prognosis of metastatic breast cancer. Breast Cancer Res Treat. 2010;122(1):211-7 (PubMed PMID: 19967556).

32. Dirix LY, Salgado R, Weytjens R, Colpaert C, Benoy I, Huget $\mathrm{P}$, et al. Plasma fibrin D-dimer levels correlate with tumour 
volume, progression rate and survival in patients with metastatic breast cancer. Br J Cancer. 2002;86(3):389-95 (PubMed PMID: 11875705, Pubmed Central PMCID: 2375200).

33. Mego M, Zuo Z, Gao H, Cohen EN, Giordano A, Tin S, et al. Circulating tumour cells are linked to plasma D-dimer levels in patients with metastatic breast cancer. Thromb Haemost. 2015;113(3):593-8 (PubMed PMID: 25373787).

34. Versteeg HH, Spek CA, Richel DJ, Peppelenbosch MP. Coagulation factors VIIa and Xa inhibit apoptosis and anoikis. Oncogene. 2004;23(2):410-7 (PubMed PMID: 14724569).

35. Milsom CC, Yu JL, Mackman N, Micallef J, Anderson GM, Guha A, et al. Tissue factor regulation by epidermal growth factor receptor and epithelial-to-mesenchymal transitions: effect on tumor initiation and angiogenesis. Cancer Res. 2008;68(24):1006876 (PubMed PMID: 19074872, Pubmed Central PMCID: 2834285).

36. Bourcy M, Suarez-Carmona M, Lambert J, Francart ME, Schroeder H, Delierneux C, et al. Tissue factor induced by epithelial-mesenchymal transition triggers a procoagulant state that drives metastasis of circulating tumor cells. Cancer Res. 2016;76(14):4270-82 (PubMed PMID: 27221703).

37. Palumbo JS, Talmage KE, Massari JV, La Jeunesse CM, Flick MJ, Kombrinck KW, et al. Tumor cell-associated tissue factor and circulating hemostatic factors cooperate to increase metastatic potential through natural killer cell-dependent and-independent mechanisms. Blood. 2007;110(1):133-41 (PubMed PMID: 17371949, Pubmed Central PMCID: 1896107).

38. Nieswandt B, Hafner M, Echtenacher B, Mannel DN. Lysis of tumor cells by natural killer cells in mice is impeded by platelets. Cancer Res. 1999;59(6):1295-300 (PubMed PMID: 10096562).

39. Kopp HG, Placke T, Salih HR. Platelet-derived transforming growth factor-beta down-regulates NKG2D thereby inhibiting natural killer cell antitumor reactivity. Cancer Res. 2009;69(19):7775-83 (PubMed PMID: 19738039).
40. Borsig L, Wong R, Feramisco J, Nadeau DR, Varki NM, Varki A. Heparin and cancer revisited: mechanistic connections involving platelets, P-selectin, carcinoma mucins, and tumor metastasis. Proc Natl Acad Sci USA. 2001;98(6):3352-7 (PubMed PMID: 11248082, Pubmed Central PMCID: 30657).

41. Dardik R, Savion N, Kaufmann Y, Varon D. Thrombin promotes platelet-mediated melanoma cell adhesion to endothelial cells under flow conditions: role of platelet glycoproteins P-selectin and GPIIb-IIIA. Br J Cancer. 1998;77(12):2069-75 (PubMed PMID: 9649116, Pubmed Central PMCID: 2150413).

42. Ngo CV, Picha K, McCabe F, Millar H, Tawadros R, Tam SH, et al. CNTO 859, a humanized anti-tissue factor monoclonal antibody, is a potent inhibitor of breast cancer metastasis and tumor growth in xenograft models. Int J Cancer. 2007;120(6):1261-7 (PubMed PMID: 17192924).

43. Versteeg HH, Schaffner F, Kerver M, Petersen HH, Ahamed J, Felding-Habermann B, et al. Inhibition of tissue factor signaling suppresses tumor growth. Blood. 2008;111(1):190-9 (PubMed PMID: 17901245, Pubmed Central PMCID: 2200804).

44. DeFeo K, Hayes C, Chernick M, Ryn JV, Gilmour SK. Use of dabigatran etexilate to reduce breast cancer progression. Cancer Biol Ther. 2010;10(10):1001-8 (PubMed PMID: 20798593).

45. Kirwan CC, Bundred NJ, Castle J, Clarke R, Dive C, Morris J, et al. PO-36 - thrombin inhibition preoperatively (TIP) in early breast cancer, the first clinical trial of NOACs as an anti-cancer agent: trial methodology. Thromb Res. 2016;140(Suppl 1):S189S190190 (PubMed PMID: 27161723).

Publisher's Note Springer Nature remains neutral with regard to jurisdictional claims in published maps and institutional affiliations. 